\title{
FURTHER STUDIES ON THE MODE OF ACTION OF CLOSTRIDIUM WELCHII TYPE-D EPSILON TOXIN
}

\author{
D. Buxton \\ Department of Pathology, Moredun Research Institute, \\ 408 Gilmerton Road, Edinburgh EH17 $7 \mathrm{JH}$
}

CLOSTRIDIUM WELCHII type $\mathrm{D}$ is responsible for a rapidly fatal enterotoxaemia of sheep, cattle and goats. The major lethal toxin of the organism is epsilon toxin. In naturally occurring enterotoxaemia the epsilon toxin damages several organs, but its primary effect is upon the intestines where it increases the permeability of the gut wall, enhances its own uptake and produces a mucoid diarrhoea (Bullen, 1970). This last symptom is usually forestalled by the death of the animal and this explains why the toxin-unlike the enterotoxin of $C$. welchii type A-is more commonly regarded as a lethal toxin than as an enterotoxin.

Vibrio cholerae enterotoxin has been shown to stimulate adenyl cyclase to produce increased amounts of cyclic adenosine 3', 5'-monophosphate (cAMP) (Sharp and Hynie, 1971; King and van Heyningen, 1973) which in turn can increase fluid production by the intestines (Sharp and Hynie, 1971). More recently Escherichia coli heat-labile enterotoxin and Staphylococcus aureus delta toxin have also been shown to stimulate the production of cAMP (Gill, Evans and Evans, 1976; O’Brien and Kapral, 1976).

In the present study the epsilon toxin of $C$. welchii type $\mathrm{D}$ was investigated for its ability to act in a similar manner. First, the ability of the toxin to promote increased vascular permeability in guinea-pig skin, by a mechanism not dependent on the release of mast-cell amines, was tested as it has been suggested that this is a cAMP-mediated response (O'Brien and Kapral, 1976); second, the ability of the toxin to raise the concentration of cAMP in mouse plasma was examined.

\section{MATERIALS AND METHODS}

Epsilon toxin and vascular permeability in guinea-pig skin. The flanks and ventral surfaces of seven Dunkin-Hartley male guinea-pigs were clipped $48 \mathrm{~h}$ before the start of the experiment to allow recovery from any mast-cell damage caused by the clipping. Fourteen standard sites were located over this area and three of the guinea-pigs were then each given $4 \mathrm{ml}$ of mepyramine maleate $(0.5 \mathrm{mg}$ per $\mathrm{ml}$ of normal saline) intraperitoneally to suppress any histamine activity. After $30 \mathrm{~min}$. each of the seven animals received $2 \mathrm{ml}$ of $0.5 \%$ Evans blue in normal saline via the recurrent tarsal vein.

Epsilon prototoxin (Dr R. O. Thomson, Wellcome Research Laboratories) was dissolved in $0.85 \%$ saline $(100 \mu \mathrm{g}$ per $\mathrm{ml})$ containing $0.1 \%$ gelatin and activated with trypsin $(0.25 \%$ wiv) at $37^{\circ} \mathrm{C}$ for $45 \mathrm{~min}$., after which soybean trypsin inhibitor was added at the same concentration. A similar solution without toxin was also prepared and termed "diluent". These two stock solutions were further diluted in saline-gelatin to give toxin concentrations of $5,10,20,50$ and $100 \mu \mathrm{g}$ per $\mathrm{ml}$ and corresponding dilutions of " diluent ". 
Four concentrations of histamine $(0.0,0.5,50$ and $500 \mu \mathrm{g}$ per $\mathrm{ml})$ in $0.85 \%$ saline containing $0.1 \%$ gelatin were also prepared for injection to assess the efficacy of the mepyramine treatment.

A $0 \cdot 1-\mathrm{ml}$ volume of each of these 14 preparations was injected intradermally into 14 randomised sites. Each set of sites was different for each guinea-pig and was obtained from the random figure tables of Cochran and Cox (1957).

Forty-five min. after inoculation each guinea-pig was stunned by a blow on the head, exsanguinated, and the skin of the trunk reflected. Vascular leakage at the site of injection was apparent as a blue circle or ellipse. The length and breadth of each of these lesions were measured " blind" (i.e., without knowledge of the test mixture) on the under surface of the skin and the area calculated; if not circular, the lesion was considered to be a true ellipse.

Epsilon toxin and cAMP levels in mouse plasma. Nine 4-week-old male Porton/ADR mice (nos. 1-9) each received intravenously $0.22 \mu \mathrm{g}$ of epsilon toxin (LD50 $0.2 \mu \mathrm{g}$ ) in $1 \%$ peptone water, and a further group (nos. 10-18) each received an equal volume of diluent by the same route. After $5 \mathrm{~h}$, each mouse was anaesthetised with ether and exactly $500 \mu \mathrm{l}$ of blood were withdrawn from an incision in the axilla and added to $5 \mu \mathrm{l}$ of a $0.5 \mathrm{M}$ solution of EDTA (to prevent clotting and inhibit phosphodiesterase), $p \mathbf{H} 7 \cdot 5$, in a chilled plastic container. Two hundred $\mu \mathrm{l}$ of plasma were removed and stored at $-20^{\circ} \mathrm{C}$ until required for assay. Cyclic AMP was assayed by a competitive protein-binding method (Radiochemical Centre, Amersham) as described by Tovey, Oldham and Whelan (1974). Each sample was assayed (A) undiluted and (B) at a dilution of 1 in 2. Two pmol of unlabelled cAMP were added to the latter dilution to act as an internal standard for the detection of interfering substances.

\section{RESULTS}

Epsilon toxin and vascular permeability in guinea-pig skin

The responses of the three mepyramine-treated guinea-pigs to histamine were minimal compared with those of the four untreated animals (fig. 1). This indicates that the antihistamine action of the mepyramine was fully effective.

The responses of the two groups to the injection of graded doses of diluent plus toxin are recorded in fig. 2 . Whilst the extent of leakage in the mepyraminetreated guinea-pigs was marginally less than that in the untreated animals in

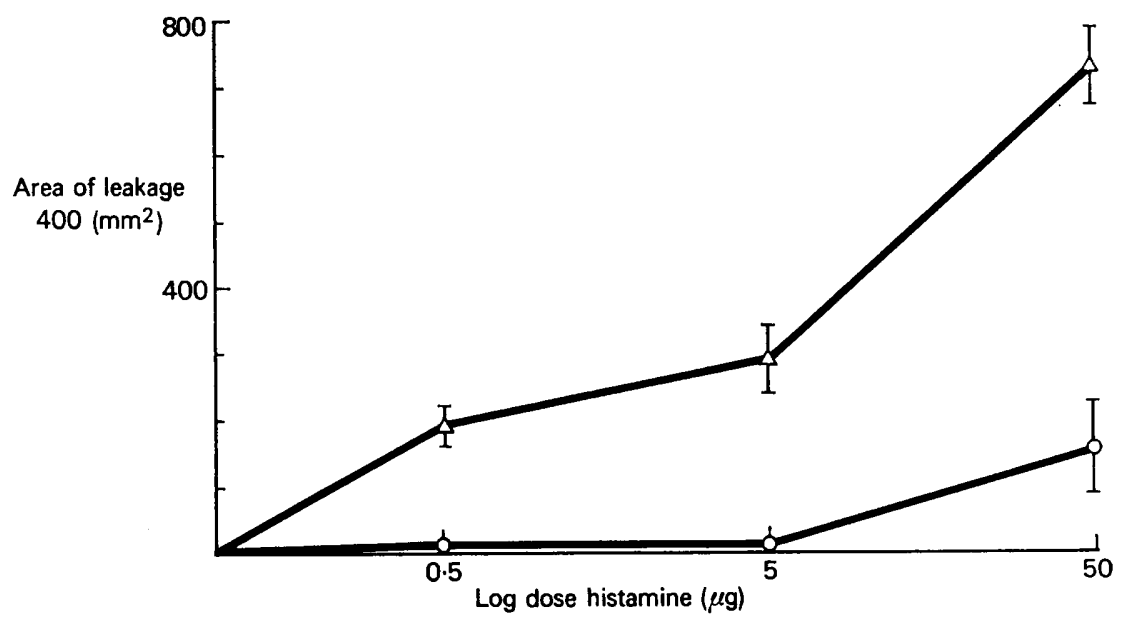

FIG 1.-Graph illustrating the effect of the antihistamine, mepyramine maleate, on the area of leakage produced by histamine in the skin of guinea-pigs: $O=$ mepyramine group; $\Delta=$ untreated group. 


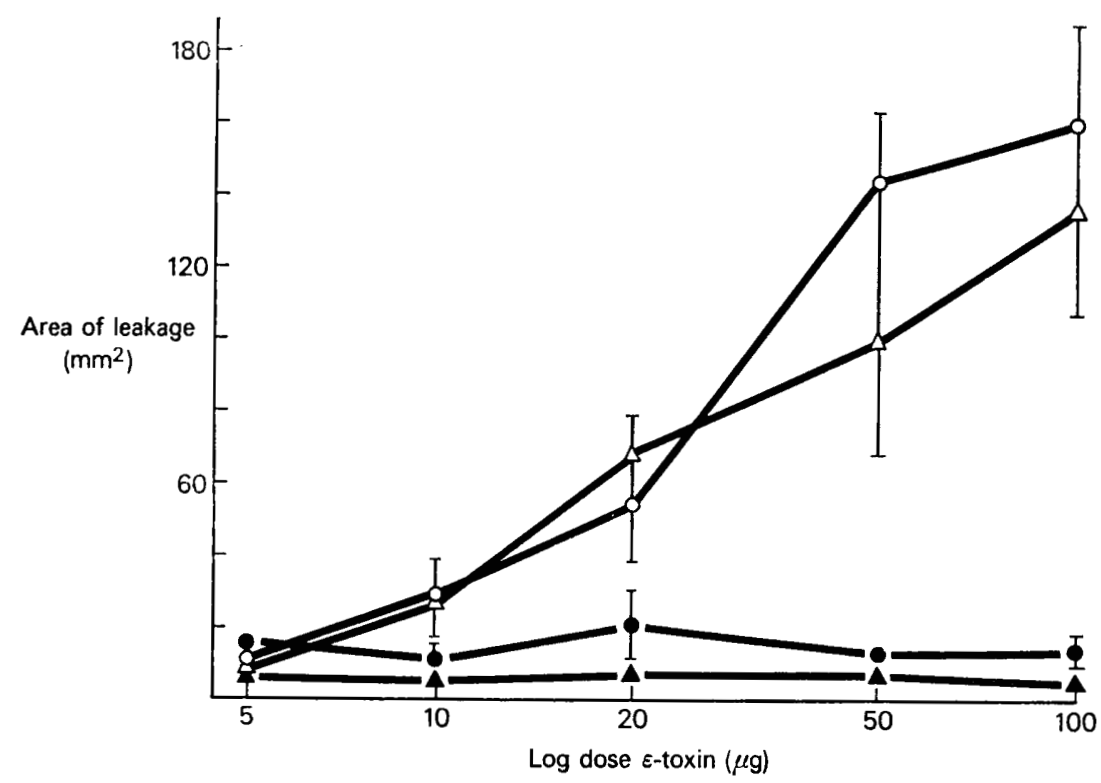

FIG. 2.-Graph illustrating the effect of the antihistamine mepyramine maleate on the area of leakage produced by epsilon toxin or " diluent" in the skin of guinea-pigs: $\bigcirc=$ toxin alone; $=$ diluent alone; $\triangle=$ mepyramine and toxin; $\Delta=$ mepyramine and diluent.

respect both of diluent and of diluent plus toxin, the results indicated that in both groups diluent alone caused a very low-grade response whereas diluent plus toxin caused increasing leakage with increasing toxin concentrations. A $(2 \times 5)$ factorial analysis showed no significant difference between the responses of untreated and mepyramine-treated guinea-pigs to epsilon toxin. Epsilon toxin therefore seems to increase vascular permeability in guinea-pig skin by a means independent of histamine.

\section{Epsilon toxin and cAMP levels in mouse plasma}

Five hours after the administration of toxin, the mice showed mild clinical signs of intoxication. The plasma concentrations of cAMP are shown in the table. The mean of the levels of cAMP in the intoxicated mice was $47 \%$ higher than that in the control group $(P=0.004)$. The fact that the levels of cAMP in the undiluted samples were very close to those diluted 1 in 2 and containing an internal standard indicates that there was minimal interference from other factors.

\section{Discussion}

Several enterotoxic bacterial exotoxins have been shown to cause increases in cutaneous vascular permeability. They include $V$. cholerae enterotoxin (Craig, 1965), E. coli heat-labile enterotoxin (Rappaport et al., 1976), Staphylococcus aureus delta toxin (O'Brien and Kapral, 1976) and culture filtrates of Salmonella typhimurium (Sandefur and Peterson, 1976). This reaction is thought to be a cAMP-mediated response (O'Brien and Kapral, 1976). 


\section{TABLE}

Effect of epsilon toxin on cAMP levels in mouse plasma

\begin{tabular}{|c|c|c|c|c|}
\hline $\begin{array}{c}\text { Mouse } \\
\text { no. }\end{array}$ & $\begin{array}{c}\text { Dose } \\
\text { of toxin } \\
(\mu \mathrm{g})\end{array}$ & Method of assay* & $\begin{array}{l}\text { cAMP per ml } \\
(\mathrm{pmol})\end{array}$ & $\begin{array}{l}\text { Increase }(\%) \text { and } \\
\text { significance } \dagger\end{array}$ \\
\hline $1-9$ & 0.22 & $\left\{\begin{array}{l}\text { A } \\
\text { B (with } 2 \text { pmol cAMP) }\end{array}\right.$ & $\left.{ }_{81}^{78}\right\}$ Mean $79 \cdot 5$ & \\
\hline $10-18$ & $\begin{array}{l}\text { Nil } \\
\text { (diluent } \\
\text { control) }\end{array}$ & $\left\{\begin{array}{l}\text { A } \\
\text { B (with } 2 \text { pmol cAMP) }\end{array}\right.$ & $\left.\begin{array}{l}56 \\
52\end{array}\right\}$ Mean 54 & $P=0.004$ \\
\hline
\end{tabular}

* See Methods.

$\dagger$ Statistics performed with two-tailed Student's $t$ test.

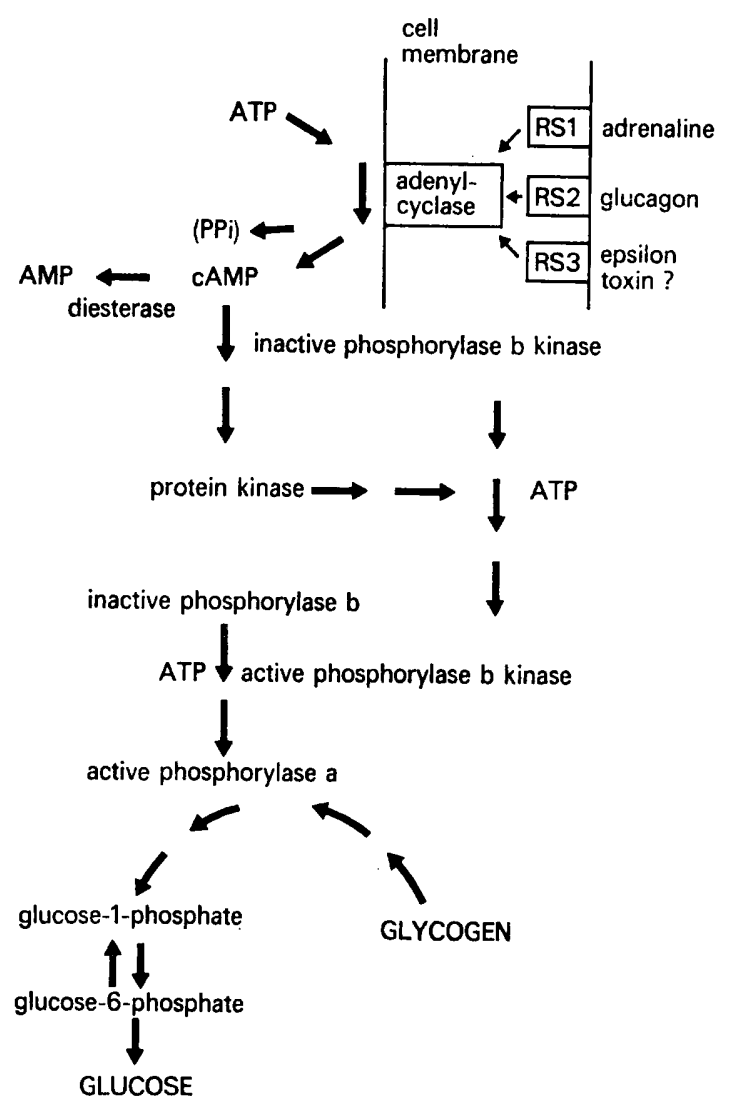

Fig. 3.-Scheme of glycogenolysis in the hepatocyte (after Conn and Stumpf, 1972) showing possible site of binding and biochemical effect of epsilon toxin. 
$V$. cholerae enterotoxin, E. coli heat-labile enterotoxin and Staph. aureus delta toxin can also stimulate the production of cAMP in in-vitro preparations of guinea-pig ileal-mucosal cells, but Staph. aureus delta toxin-unlike the other two-is also cytotoxic (O'Brien and Kapral, 1976) as is epsilon toxin (Buxton and Morgan, 1976).

In the present study it has been shown that epsilon toxin is also able to increase vascular permeability by a mechanism that does not involve the release of mast-cell amines; furthermore it can raise plasma cAMP concentrations in mice. It is not possible to say whether the increase in plasma cAMP was due to direct stimulation of adenyl cyclase or to some other mechanism such as inhibition of phosphodiesterase. However, in view of the similarities between the properties of epsilon toxin and some other enterotoxins it seems likely that epsilon toxin also stimulates adenyl cyclase.

If this is so, the dramatic increase in blood glucose that occurs in the preclinical phase of $C$. welchii type-D intoxication (Gordon et al., 1940; Bullen and Scarisbrick, 1957; Gardner, 1973 $a$ and $b$ ) may be due to hepatocyte-bound epsilon toxin (Buxton, 1978) stimulating cAMP production through membraneassociated adenyl cyclase and thus causing breakdown of glycogen into glucose (fig. 3).

It is considered that $C$. welchii type-D epsilon toxin is an enterotoxin capable of causing widespread damage by binding to specific receptor sites located on the surfaces of certain cells (Buxton, 1978). The detailed mechanism of its mode of action remains to be elucidated, but the results of the present work indicate that an adenyl cyclase-cAMP system may be important.

\section{SUMMARY}

Intradermal injection of Clostridium welchii type-D epsilon toxin increased the permeability of blood vessels in guinea-pig skin to Evans blue dye by a mechanism not dependent on the release of histamine. The toxin was also found to raise the plasma concentration of cyclic adenosine $3^{\prime}, 5^{\prime}$-monophosphate in mice. It is concluded that epsilon toxin is an enterotoxin capable of causing widespread damage, after binding to receptor sites on the surface of certain cells, through a mechanism mediated by an adenyl cyclase-cAMP system.

I should like to thank Dr R. M. Barlow, Professor J. G. Collee, Dr B. S. W. Smith and $\mathrm{Mr} \mathbf{H}$. Wright for helpful discussion and Mrs J. Finlayson and Mr B. Easter for technical assistance.

\section{REFERENCES}

Bullen, J. J. 1970. Role of toxins in host-parasite relationships. In Microbial toxins, edited by S. J. Ajl, S. Kadis and T. C. Montie, New York and London, vol. 1, p. 233.

Bullen, J. J. AND SCARISBRick, R. 1957. Enterotoxaemia of sheep: experimental reproduction of the disease. J. Path. Bact., 73, 495.

Buxton, D. 1978. The use of an immunoperoxidase technique to investigate by light and electron microscopy the sites of binding of Clostridium welchii type-D epsilon toxin in mice. J. med. Microbiol., 11, 289.

Buxton, D. And Morgan, K. T. 1976. Studies of lesions produced in the brains of colostrum deprived lambs by Clostridium welchii (Cl.perfringens) type D toxin. J. comp. Path., 86, 435. 
Cochran, W. G. and Cox, G. M. 1957. Experimental designs, 2nd ed., London.

ConN, E. E. AND StUMPF, P. K. 1972. Outlines of biochemistry, 3rd ed., New York.

CraIg, J. P. 1965. A permeability factor (toxin) found in cholera stools and culture filtrates and its neutralisation by convalescent cholera sera. Nature, Lond., 207, 614.

GARDNER, D. E. 1973a. Pathology of Clostridium welchii type D enterotoxaemia. I. Biochemical and haematological alterations in lambs. J. comp. Path., 83, 499.

GARDNeR, D. E. 1973b. Pathology of Clostridium welchii type D enterotoxaemia. III. Basis of the hyperglycaemic response. J. comp. Path., 83, 525.

Gill, D. M., Evans, D. J. AND Evans, D. G. 1976. Mechanism of activation of adenylate cyclase in vitro by polymyxin-released, heat-labile enterotoxin of Escherichia coli. $J$. infect. Dis., 133, Suppl., S103.

Gordon, W. S., Stewart, J., Holman, H. H. AND TAYloR, A. W. 1940. Blood changes and post-mortem findings following intravenous inoculation of sheep with culture filtrates of Clostridium welchii types A, C and D. J. Path. Bact., 50, 251.

KING, C. A. AND VAN HeYningen, W. E. 1973. Deactivation of cholera toxin by a sialidaseresistant monosialosylganglioside. J. infect. Dis., 127, 639.

O'BrIEN, A. D. AND KAPRAL, F. A. 1976. Increased cyclic adenosine 3',5'-monophosphate content in guinea pig ileum after exposure to Staphylococcus aureus delta toxin. Infect. Immun., 13, 152.

Rappaport, R. S., Sagin, J. F., Pierzchala, W. A., Bonde, G., Rubin, B. A. and Tint, H. 1976. Activation of heat-labile Escherichia coli enterotoxin by trypsin. J. infect. Dis., 133, Suppl., S41.

Sandefur, P. D. AND Peterson, J. W. 1976. Isolation of skin permeability factors from culture filtrates of Salmonella typhimurium. Infect. Immun., 14, 671.

Sharp, G. W. G. AND HynIE, S. 1971. Stimulation of intestinal adenyl cyclase by cholera toxin. Nature, Lond., 229, 266.

Tovey, K. C., Oldham, K. G. AND Whelan, J. A. M. 1974. A simple direct assay for cyclic AMP in plasma and other biological samples using an improved competitive protein binding technique. Clinica Chim. Acta, 56, 221. 